\title{
OPEN QUESTIONS IN CALIFORNIA'S ADOPTION OF THE DOCTRINE OF FORUM NON CONVENIENS
}

By a sweeping decision in the recent case of Price v. Atchison, $T$. and S.F. Ry. Co. ${ }^{1}$ the California Supreme Court has sanctioned the application of the controversial doctrine of forum non conveniens ${ }^{2}$ in this state. Henceforth, a trial court may properly decline to retain jurisdiction over a transitory cause of action which has arisen outside of the state, if it believes such a refusal will be inore convenient to the court, to the parties, and in the interest of justice.

The Price case involved principally the making of an important policy determination. Many state courts have been faced with bitter allegations in recent years that plaintiffs were abusing the liberal venue provisions of the Federal Employers' Liability Act ${ }^{3}$ by engaging in widespread "shopping of forums" in search of inore generous jury verdicts. ${ }^{4}$ On the federal level, Congress responded to this criticism by the passage of Section $1404(a)^{5}$ of the Federal Judicial Code. This provision authorizes transfer of transitory actions from one district court to another on the apparent basis of the doctrine of forum non conveniens. However, FELA actions may be instituted in the court of any state in which the cause of action arose or in which the defendant resides, and removal of these actions to an

142 Cal.2d 577, 268 P.2d 457 (1954), cert. denied, 23 Law Week 3094 (1954).

2 By 1947 , the doctrine was declared to be accepted generally only in the states of Florida, Louisiana, Massachusetts, New Hampshire, New Jersey and New York. Barrett, The Doctrine of Forum Non Conveniens, 35 CALIF. L. REv. 380, 389 (1947). To this list may be added Utah [Mooney v. Denver and R. G. W. R. Co., 118 Utah 307, 221 P.2d 628 (1950)] and Illinois [Whitney v. Madden, 400 III. 185, 79 N.E.2d 593 (1948)]. The federal district courts are authorized to transfer actions to other federal courts under the Revised Judicial Code. 28 U.S.C. \$ 1404(a) (1952).

For discussions of the doctrine generally see Barrett, The Doctrine of Fortm Non Conveniens, supra (1947); Braucher, The Inconvenient Federal Forum, 60 HARv. L. REv. 908 (1947); Johnson and Poland, Forum Non Conveniens and the Federal Employers Liability Act, 17 J.B.A. Kan. 486 (1949).

345 U.S.C. $\$ \$ 51-59$ (1952). The Act provides that “. . . an action may be brought in a district court of the United States, in the district of the residence of the defendant, or in which the cause of action arose, or in which the defendant shall be doing business at the time of cominencing such action. The jurisdiction of the courts of the United States under this chapter shall be concurrent with that of the courts of the several States." 45 U.S.C. \$ 56 (1952).

4 An extreine example of such "shopping" is illustrated in a case involving the same railroad. Atchison, T. and S.F. Ry. Co. v. Andrews, 338 Ill. App. 552, 88 N.E.2d 364 (1949) (attorney had solicited and instituted actions in Chicago claiming approximately $\$ 5,000,000$ in FELA daunage claims froin causes of action which arose in Cahfornia, Arizona and other western states). The Supreme Court of Utah strongly condemned the "importing" of lawsuits when it approved application of fortm non conveniens in that state. Mooney v. Denver and R. G. W. Ry. Co., 118 Utah 307, 337, 221 P.2d 628, 646 (1950) (" . . the number of cases imported into a particular state is in direct proportion to the size of verdicts rendered.") For discussions expressing differing viewpoints as to the desirability of such practice, see Gibson, The Venue Clause and Transportation of Lawsuits, 18 LAw \& ConTEMP. ProB. 367 (1953) and Griffith, The Vindication of a National Public Policy Under the Federal Employers' Liability Act, 18 LAW \& CONTEMP. PROB. 160 (1953).

528 U.S.C. $\$ 1404$ (a) (1952): "For the convenience of parties and witnesses, in the interest of justice, a district court may transfer any civil action to any other district or division where it might have been brought." 
appropriate federal tribunal is expressly disallowed. ${ }^{6}$ Attempts by the railroad companies, defendants in FELA actions, to modify the venue features of that Act have not been fruitful. ${ }^{7}$ Consequently their efforts have been confined to encouraging individual states to adopt forum non conveniens and apply it in FELA cases. ${ }^{8}$

In the Price case, the plaintiff was a citizen and resident of New Mexico. He was injured in that state in the employ of defendant, a Kansas corporation doing business in both New Mexico and California. Action was brought under the provisions of the FELA in a California superior court. Defendant, inter alia, prayed for a dismissal on grounds of forum non conveniens, alleging by affidavit the great expense involved in bringing witnesses 800 to 1000 miles to testify and charging plaintiff's attorneys with having "imported" sixty-seven such out-of-state FELA actions involving the defendant into the Los Angeles County Superior Court. ${ }^{9}$ The dismissal was granted, but was reversed by the District Court of Appeal, which relied upon its recent decision in Schultz v. Union Pacific R.R. Co ${ }^{10}$ The California Supreme Court, although it had refused to grant a hearing in the Schultz case, affirmed the trial court. The majority opinion recognized that it had decided in Leet v. Union Pacific R.R. Co. ${ }^{\text {i1 }}$ that forum non conveniens was not available in FELA cases. However, declared the court, this decision was predicated on the mistaken notion that the very provisions of the Act precluded invocation of the doctrine. The United States Supreme Court dispelled this erroneous interpretation in Southern R. Co. v. Mayfield, ${ }^{12}$ declaring the doctrine fully applicable by the states so long as FELA suits were not discriminated against nor the privileges and immunities clause ${ }^{13}$ of the Constitution violated. The California Supreme Court in the Price case took full advantage of this go-ahead signal and declared forum non conveniens to be available in any transitory action where the facts justify such a dismissal. It repudiated the reasoning in the Schultz case by asserting that an impartial administration of the doctrine in no way conflicted with the privileges and immunities clause.

Whether California has taken a progressive step forward by this de-

6 28 U.S.C. $\$ 1445$ (a) (1952).

7 In 1947, the House of Representatives passed the Jennings Bill which would have required the plaintiff to bring his FELA action either where the cause of action arose or where the defendant resided at the time of the suit. H. R. REP. No. 613, 80th Cong., 1st Sess. (1947) (Report on H. R. 1639). The bill died, however, in the Senate Judiciary Committee.

8 Attempts by the California Legislature in 1953 to adopt forum non conveniens by statute were frustrated by failure to gain gubernatorial approval. 1953 Session, S. B. 789; 1953. Session S. B. 1960.

'Plaintiff's attorneys were also accused in the pleadings and affidavits of having brought 21 such actions involving defendant in the federal district court in the state. Price v. Atchison, T. and S. F. Ry. Co., 42 Cal. 2d 577, 580, 268 P.2d 457, 458 (1954).

10118 Cal. App.2d 169, 257 P.2d 1003 (1953). See Note, 41 CALTF. L. Rev. 755 (1953).

$1125 \mathrm{Cal} .2 \mathrm{~d} 605,155$ P.2d 42 (1944).

12340 U.S. 1 (1950).

13 "The citizens of each state sball be entitled to all privileges and immunities of the citizens in the several states." U. S. CoNsT. Art. IV, § 2. 
cision may be arguable. ${ }^{14}$ However, the real and pressing problem which confronts the state's courts is: now that forum non conveniens has been approved, what are to be the limitations to guide the trial judge in the exercise of his discretion? Not all suits in which the courts will be called upon to apply the doctrine will involve fact situations as compelling as in the instant case. Yet, the majority holding laid down no specific criteria other than noting the very vague principles set forth by the United States Supreme Court in Gulf Oil Corp. v. Gilbert ${ }^{15}$ to guide the federal district courts in applying Section 1404(a). Thus the trial court should consider the private interests of the litigants, availability of witnesses, access to proof and relative ease in conducting the trial, and then decide the dispute in an enlightened manner. Certainly those principles will serve as no better guides for California courts than they have for the federal tribunals. Since passage of Section 1404(a), a host of case law has accumulated fully illustrating the lack of uniformity among these courts in applying the doctrine..$^{16}$ As a federal district judge stated in United States v.E.I. du Pont de Nemours \& Co.:17

To attempt to resolve the niceties involved in balancing the relative conveniences and inconveniences of all of the parties to any degree of certainty, resort must be had to an apothecary's scale and a crystal ball; neither of which implements are available to this court.

The practicing attorney can only speculate as to what dismissals will be considered abuses of discretion in the eyes of the California courts.

\section{Scope of Appellate Review}

The availability and scope of appellate review of orders granting or denying dismissals is uncertain. Undoubtedly the plaintiff may directly appeal a trial court's decision invoking forum non conveniens. However, as discussed infra, the statute of limitations complicates the administration of the doctrine in the states. Often the plaintiff may find that the prolonged litigation exposes him to the risk that during the course of his appeal the statute may run its course in the "more convement" forum.

Whether the defendant is entitled to review at all from a denial of a dismissal is certainly not clear. The court merely pronounced: ${ }^{18}$

14 "The holding of the majority in this case injects into the law of this state for the first time in its entire judicial history the most monstrous weapon for obstructing the administration of justice ever conceived by any court or judicial tribunal." Price v. Atchison, T. and S. F. Ry. Co., 42 Cal.2d 577, 587, 268 P.2d 457, 463 (1954) (dissenting opinion).

15330 U.S. 501, 507-509 (1947).

16 Soune of the discussions of the operation of Sec. 1404(a) include: Coinment, Factors of Choice for Venue Transfer under 28 U.S.C. Sec. 1404(a), 41 CALIF. L. Rev. 507 (1953); Kaufman, Observations on Transfers under Section 1404(a) of the New Judicial Code, 10 F.R.D. 595 (1951); Keefe et al., Venue and Removal Jokers in the New Federal Judicial Code, 38 VA. L. REv. 569 (1952); Note, Limitation on the Transfer of Actions Under the Judicial Code, 64 HARV.L. REv. 1347 (1951).

1787 F.Supp. 962, 965 (N.D. IIl. 1950).

18 Price v. Atchison, T. and S. F. Ry. Co., 42 Cal.2d 577, 579, 268 P.2d 457, 458 (1954). (Italics added). 
We have concluded that upon a proper showing and within the limitations imposed by the privilege and immunities clause of the federal Constitution (Art. IV , § 2) the doctrine may be applied in this state.

Assuming, however, that the Price case requires the trial judge to dismiss "upon a proper showing," when may the defendant properly appeal? Justice. Carter, the lone dissenter in the principal case, observed that a denial of a dismissal was an interlocutory order, and hence not appealable. ${ }^{19} \mathrm{He}$ feared that a decision upon the merits of the cause of action in favor of the plaintiff could be upset on appeal where it was found that defendant was entitled to a dismissal on the basis of forum non conveniens. However, the defendant would be required to demonstrate not only that the lower court abused its discretion in retaining jurisdiction, but also, as a result, that he "sustained and suffered substantial injury, and that a different result would have been probable if such . . . ruling . . . had not occurred. . . " 20 It may be argued that dismissal of the cause of action is clearly a "different result." It appears more likely, however, that the defendant will necessarily have to show that had the action been brought elsewhere, a different decision would have been reached. This burden may prove to be insurmountable. It is wholly speculative whether, for example, the personal appearance of certain far-away witnesses, rather than presentation of their depositions, would have resulted in a different decision in another forum.

The logical point from which an appeal should be taken by the defendant is upon the order denying the dismissal. This could be provided for by legislative amendment to Section 963 of the Code of Civil Procedure. ${ }^{21}$ However, weighing against such a concession to the assertion of defendant's legal rights would be the burdensome delay and expense to the plaintiff resulting from prolonged litigation of the preliminary issue of place of trial.

\section{Statute of Limitations}

One feature differentiating Section 1404(a) and California's newlyadopted forum non conveniens is that, under the former, an action begun in one district court is not subject to dismissal but is transferred to a more appropriate federal tribunal. Thus jurisdiction as such is still retained. However, there is no method of transfer available between states. If plaintiff's suit brought in state $A$ is dismissed, he may find that the statute of limitations now bars his instituting an action in state $B$, where his cause of action arose. One obvious solution would be to file complaints in both jurisdictions. The practicality of this device would depend upon the procedural

${ }^{10}$ CaL. Code Crv. Proc. $\$ 963$ appears to substantiate Justice Carter's conclusion.

20 CAL. COde Crv. Proc. $\$ 475$.

21 At present this section authorizes an immediate appeal from an order "changing or refusing to change the place of trial." Amending the statute to allow appellate review "from orders granting or denying dismissals under the doctrine of fortm non conveniens" would not be a radical departure from the present pattern of California's procedural law. 1953 Session, S. B. 1960, an unsuccessful legislative attempt to adopt the doctrine im California, explicitly provided that an interlocutory order thereunder was an appealable order. 
laws of state $B$. If the statute is tolled upon filing the action in that state, and not upon service of summons, invocation of forum non conveniens would probably carry no drastic consequences; the plaintiff can proceed to serve process on defendant in state $B$ after the dismissal. Assuming, lrowever, that this course is unavailable or impractical for the plaintiff and that action is instituted only in state $A$-should a dismissal be granted when the result will foreclose lis cause of action forever?

Although counsel did not raise this problem in the Price case, ${ }^{23}$ the court dealt with it. It declared, "[I]f plaintiff chooses without justification to bring his action under circumstances warranting application of the doctrine it is a deliberate risk assumed by him and he must be prepared to meet any losses sustained as a result." ${ }^{24}$ Under FELA cases, points out the court, if plaintiff is really worried about the effects of a dismissal, he should bring his suit in a federal court.

Does the court mean by "without justification" that a dismissal will not be granted if plaintiff can show (1) his suit was brought in California in good faith and (2) application of forum non conveniens will terminate his cause of action forever? Or is the implication that whenever plaintiff knows, or should know, that the circumstances by which the doctrine may be applied are present, he is, ipso facto, concluded to have filed his coinplaint in California "without justification"?

Assume a case where plaintiff is injured in Nevada but is treated for his injuries in California. Action is instituted in the latter state because plantiff contends that the doctors' testimony will be highly important to his case in determining damages. Assume further that by the time the issue of forum non conveniens would be finally settled, including any appeals, the statute of limitations would bar the action in Nevada. Would dismissal of the suit be consistent or in conflict with the Price decision?

Justice Carter, in his dissent, urges that an action should never be dismissed when to do so will permanently bar the plaintiff of his remedy. ${ }^{25}$ However, such a rule would result in evasion of the doctrine of fortum non conveniens by delay in serving process upon the defendant in the California action until the statute of limitations had run elsewhere.

Whether the majority's holding establishes a "good faith" test or not, it still remains open to criticism. The burden upon a trial judge to declare with convincing assuredness that plaintiff was with or without "justification" in bringing his suit in this state may often be extremely onerous. On the other hand, a policy of wholly ignoring the effect of the statute of limi-

22 E.g., CAL. Code Civ. Proc. \$ 350.

23 The dismissal by the trial court actually resulted in a foreclosure of one phase of the plaintiff's cause of action by the running of the statute of limitations. However, on appeal, defendant had stipulated to a reversal of the judgment on this cause of action. The supreme court accepted the stipulation influenced in great part by a desire not to punish plaintiff for his rehance upon the Leet case.

24 Price v. Atchison, T. and S.F. Ry. Co., 42 Cal.2d 577, 586, 268 P.2d 457, 462 (1954).

${ }^{25}$ Apparently this is the pohicy that the states recognizing forum non conveniens generally follow. Barrett, The Doctrine of Forum Non Conveniens, 35 CArrF. L. REv. 380, 419-420 (1947). 
tations can not be reconciled with an intent to apply forum non conveniens in the "interest of justice."

One possible answer to the problem, not raised or discussed by the majority, would effectively carry out the basic purposes of the doctrine of forum non conveniens and yet not deprive a plaintiff of a legitimate claim. ${ }^{26}$ Trial courts could be given discretionary power to grant dismissals conditionally upon the defendants' agreements not to raise the statute as an affirmative defense in the transferee courts. In this manner, a defendant would be prevented from urging the doctrime solely to avoid defense of the action upon the merits; the plaintiff, in addition, would not be subjected to the severe consequences that may result from an unfortunate choice of forum. Justice Carter pointed out that one of the two legislative measures proposing forum non conveniens in this state in 1953 (neither received gubernatorial approval) provided for similar protection in some detail. ${ }^{27}$ It required the defendant to stipulate, by written agreement, that not only would he waive the statute of himitations defense in the "more convemient" jurisdiction, but that he would voluntarily make a general appearance or be subject to the process of a court in that state, subject to the power of the

$2 B$ This was suggested by one writer some years ago as a solution to the troublesome problem. Foster, Place of Trial-Interstate Application of Intrastate Methods of Adjustment, 44 HARV. L. REv. 41, 50 (1930).

271953 Session, S. B. 1960:

"5. By the court, upon motion of the defendant made at or before the time of demurring or answering, when it appears from affdavits or otherwise that the cause of action did not arise within this State, and that at the time the cause of action arose the plaintiff was not a resident of this State, and that a court of this State is not a convenient forum for the parties and witnesses and that the dismissal of the action will serve the interests of justice. If the court determines to grant the motion, it shall make an interlocutory order which shall impose such conditions as the court in its discretion deems just and reasonable, but, in any event, such interlocutory order shall require that there be filed in the action a written agreement executed by the moving defendant and such other defendants as the court shall determine, which agreement as to each such defendant shall contain

"(a) Such stipulations as may be necessary to provide effectively that plaintiff may bring and maintain an action upon the same cause of action in such jurisdiction or jurisdictions as the court shall determine or, if such action cannot be brought and maintained in any such jurisdiction, that the interlocutory order and any final dismissal shall be vacated and that the time within which the action must be brought to trial shall commence on the date when the interlocutory order or dismissal is so vacated; and

"(b) Such stipulations as may be necessary to suspend effectively all statutes of limitations which have not expired at the time the action was commenced for a period sufficient to make effective the provisions of the foregoing subdivision (a) which period shall he not less than 180 days after the dismissal shall become final; and

"(c) Such stipulations as may be necessary to assure that the moving defendant, and such other defendants as the court shall determine, will voluntarily make a general appearance in, or be subject to the process of a court in the jurisdiction or jurisdictions determined by the court as provided in subdivision (a).

"Upon proof that the conditions of the interlocutory order have been performed within the time allowed, the court, upon motion, shall thereupon enter a judgment of dismissal. If the conditions are not performed, the court, upon motion, shall vacate the interlocutory order and enter an order denying the motion or make such other order as is just. An interlocutory order hereunder is an appealable order.

"The party making the motion shall have the burden of proof that the cause of action did not arise within this State, that a court of this State is not a convenient forum for the parties and witnesses and that dismissal will serve the interests of justice."

The other measure was 1953 Session, S. B. 789. 
California court to vacate its interlocutory order and deny the motion upon defendant's failure to perform the conditions. Since the California Supreme Court apparently does not contemplate the granting of conditional dismissals, legislative enactment is desirable.

\section{Conclusion}

The adoption of forum non conveniens may prove to be a great asset in curbing the practice of forum-shopping in California. However, unless the supreme court enunciates clearer criteria to guide the trial judges, drawn out litigation concerning application of the doctrine may result in its fostering serious injustice. The California Legislature likewise has an important role in providing for equitable administration of forum non conveniens in this state. Prompt action by both bodies may prevent the doctrine from working an undue hardship upon plaintiffs, defendants, or the courts of California. 